\title{
The fate of some pesticides in Finnish cultivated soils
}

\author{
HANNU BRAUNSCHWEILER
}

BRAUNSCHWEILER, H. 1992. The fate of some pesticides in Finnish cultivated soils. Agric. Sci. Finl. 1: 37-55. (University of Helsinki, Department of Environmental Conservation, Viikki, SF-00710 Helsinki, Finland.)

The persistence and movement of methabenzthiazuron, metazachlor, trifluralin, iprodione, fenitrothion, fenvalerate and furathiocarb was studied in one growing season in cultivated clay, finesand and organic soils in southern Finland. Trifluralin was studied for two growing seasons.

Methabenzthiazuron was the most mobile pesticide and metazachlor was almost as much mobile. They leached at least $15 \mathrm{~cm}$ in a month. Fenitrothion and fenvalerate were the most immobile.

Trifluralin was the most and fenitrothion the least persistent. The concentrations of iprodione and fenvalerate in the top soils increased towards the autumn, presumably due to leaching of pesticides from plants. The residues of trifluralin measured in the surface layer of the mineral soils at the end of the growing season might have been harfmul to plants sensitive to trifluralin. The residues of trifluralin in the peat soil surface 1.5 years after the treatment were still high. Also methabenzthiazuron, iprodine and fenvalerate residues may in all probability have been detected in the following spring. If the half-life of a pesticide is over $80-100$ days, it is likely that residues of it may be found in the spring following the application in cultivated Finnish soils.

Key words: persistence, mobility, pesticide, methabenzthiazuron, metazachlor, trifluralin, iprodione, fenitrothion, furathiocarb, field study, southern Finland

\section{Introduction}

The evaluation of the fate of pesticides in Finnish environmental conditions using results obtained in foreign research work is difficult. The most valuable sources for assessments have been laboratory studies made in low soil temperatures, as well as field studies about the behaviour of pesticides in soils in other Nordic countries and Canada.

For example WALKER (1987 a) has calculated that if the half-life of a pesticide is 30 days in a laboratory study in $20^{\circ} \mathrm{C}$, its half-life estimated with a computer simulation model for the climatic conditions of northern Europe would be $1-2$ month in summer and 4 - 6 months in winter. However, he states that in practice pesticides have been less persistent in field conditions than estimates for their persistence based on laboratory results. Generally it is estimated that as the temperature raises ten degrees, the degradation rate increases 2.5 - 3 fold (ARNOLD and BRIGGS 1990). HEINONENTANSKI (1989) observed in a laboratory study with conditions approximating the climatic conditions of northern Finland that the degradation rate of glyphosate was reduced to one-tenth or onefifteenth of the initial value when the temperature decreased by ten degrees. On the other hand, when the temperature was raised by ten degrees, the degradation rate increased by 3.7 - 4 fold.

As pesticide studies applicable for Finnish environmental conditions are only few at the moment, there is a great demand for such field 
studies. Moreover it is important to study also the fate of the degradation products of pesticides in local conditions, as there is generally even less information available about them than for active ingredients.

The objective of this study was to compare the fate of three herbicides, one fungicide and three insecticides and some of their degradation products in Finnish cultivated soils with the results of similar foreign laboratory and field studies. Methabenzthiazuron is a selective herbicide used for annual weeds. In Finland it is recommended that its use in consecutive years in the same field should be avoided, because it may remain in the soil until the following growing period. The acetanilide herbicide metazachlor is used to control grasses and broadleaved weeds. It is not recommended for use in organic soils in Finland. Trifluralin is recommended for the pre-emergence control of annual grasses and broad-leaved weeds incorporated in the soil. It is not effective enough when the contents of organic material is more than $10 \%$ in the soil. In Finland it is recommended that its use in consecutive years in the same field should be avoided, because it may remain in soil until the following growing season. Iprodione is a fungicide especially effective in the control of Botrytis, Monilia and Sclerotium species.
In Finland it should not be used in consecutive years in the same field. RP-30228 is a degradation product of iprodione. Fenitrothion is an organophosphorus contact insecticide against wide range of pests. Its major breakdown product is 3-methyl-4-nitrophenol. Fenvalerate is a synthetic pyrethroid contact insecticide. Furathiocarb is a systemic carbamate insecticide effective against soil-dwelling insects and early-season pests. It is used in Finland as a seed pellet treatment. Furathiocarb degrades mainly to carbofuran which is also a systemic acaricide, insecticide and nematocide.

\section{Material and methods}

The field studies were made during the years 1985 - 1988 at the Institute of Plant Protection of the Agricultural Research Centre in Jokioinen, Southern Finland $\left(60^{\circ} 49^{\prime} \mathrm{N}\right.$ and $\left.23^{\circ} 30^{\prime} \mathrm{E}\right)$. The pesticides were studied in three soils: clay, fine sand and organic soils (humus or peat soils). The metazachlor studies were made in two different clay soils and in a finesand soil. All the soils contained at least $3-6 \%$ of humus. The properties of the soils analyzed at the Institute of Crop and Soil Science of the Agricultural Research Centre are presented in Table 1.

Table 1. The properties of the soils investigated. The concentrations are presented as $\mathrm{mg} / \mathrm{l}$ in dry weight or percentage per weight. A slash (-) indicates that there is no analysis made.

\begin{tabular}{|c|c|c|c|c|c|c|c|}
\hline $\begin{array}{l}\text { Study plot/ } \\
\text { Soil type }\end{array}$ & $\begin{array}{c}\text { Clay } \\
\%\end{array}$ & $\begin{array}{c}\text { Humus } \\
\%\end{array}$ & $\mathrm{pH}$ & $\begin{array}{c}\mathrm{Ca} \\
\mathrm{mg} / 1\end{array}$ & $\begin{array}{c}\mathrm{K} \\
\mathrm{mg} / \mathrm{l}\end{array}$ & $\begin{array}{c}\mathrm{Mg} \\
\mathrm{mg} / \mathrm{l}\end{array}$ & $\begin{array}{c}\mathrm{P} \\
\mathrm{mg} / \mathrm{l}\end{array}$ \\
\hline \multicolumn{8}{|c|}{ Metazachlor (1985) } \\
\hline Finesand & 23 & 3.9 & 6.3 & 1550 & 200 & 145 & 29 \\
\hline Clay & 62 & 4.7 & 6.1 & 2550 & 240 & 660 & 5.4 \\
\hline Mud clay & 71 & 7.8 & 6.0 & 2550 & 220 & 360 & 10 \\
\hline \multicolumn{8}{|c|}{ Iprodione and fenvalerate (1986) } \\
\hline Finesand & 18 & 4.4 & 6.5 & 3600 & 320 & 900 & 16 \\
\hline Heavy clay & 59 & 6.0 & 6.9 & 3050 & 170 & 420 & 33 \\
\hline Mould soil & - & 26 & 6.3 & 3000 & 400 & 520 & 17 \\
\hline \multicolumn{8}{|c|}{ Methabenzthiazuron and trifluralin (1987) } \\
\hline Finesand & 15 & 4.1 & 6.7 & 2120 & 410 & 140 & 58 \\
\hline Heavy clay & 64 & 9.2 & 5.8 & 2400 & 320 & 540 & 7.5 \\
\hline Carex peat & - & 41 & 5.5 & 2750 & 240 & 520 & 8.8 \\
\hline \multicolumn{8}{|c|}{ Fenitrothion and furathiocarb (1988) } \\
\hline Finesand & 14 & 3.9 & 6.3 & 2020 & 210 & 380 & 9.5 \\
\hline Clay & 54 & 5.8 & 5.8 & 2200 & 210 & 520 & 6.5 \\
\hline Mould soil & - & 25 & 6.3 & 2300 & 170 & 500 & 9.0 \\
\hline
\end{tabular}


The pesticides studied had not been used for at least the four previous years on the study plots.

For each pesticide two plots of c. $60-70 \mathrm{~m}^{2}$ were established for each soil type in cultivated fields. Only the fenitrothion and furathiocarb studies were made in the same field plots. One of the plots was treated with the pesticide according to instructions for use for the pesticide concerned. The other was kept as an untreated control plot for the chemical analysis. The study plots were sown with turnip rape except the methabenzthiazuron plot on which onion planting sets were grown. The potential maximum initial concentrations of the pesticides in the top soils (Table 2) were calculated from the amount of pesticide applied divided by the amount of the soil layer $0-5 \mathrm{~cm}$ deep. The other details of the treatments are also shown in Table 2. The weather conditions during the field experiments are presented in Table 3.

The soil samples were taken a day and a month after the treatment and when the growing season had terminated. In the furathiocarb study the first samples were taken 43 days after the start of the study. Peat soil treated with trifluralin was also sampled in the autumn of the year after the treatment, till which time the plot was neither tilled nor cultivated. Samples were taken from each plot from three soil layers: $0-5 \mathrm{~cm}, 5-15 \mathrm{~cm}$ and

Table 2. Details of the pesticide treatments. The amount of pesticide applied is given as $\mathrm{kg} / \mathrm{ha}$ for the active ingredient, except for furathiocarb $\mathrm{g} / \mathrm{kg}$ of seeds. The maximum initial concentrations in the top soil $(0-5 \mathrm{~cm})$ are calculated as mg/kg for dry weight. Trifluralin was incorporated in the soil about $0-5 \mathrm{~cm}$ deep after the treatment. The spraying of iprodione was done for a flowering field plot. In the fenvalerate study permethrin was also applied in 12.6.. The fenitrothion and furathiocarb studies were done in the same field plots. The sowing dates for metazachlor has not been registered. For furathiocarb the date of treatment is the sowing date.

\begin{tabular}{|c|c|c|c|c|c|}
\hline $\begin{array}{l}\text { Pesticide/ } \\
\text { Soil type }\end{array}$ & $\begin{array}{l}\text { Formulation/ } \\
\text { Trade mark }\end{array}$ & $\begin{array}{l}\text { Date of } \\
\text { sowing/planting }\end{array}$ & $\begin{array}{l}\text { Date of } \\
\text { treatment }\end{array}$ & $\begin{array}{l}\text { Amount } \\
\text { applied }\end{array}$ & $\begin{array}{l}\text { Maximum initial } \\
\text { concentration }(\mathrm{mg} / \mathrm{kg})\end{array}$ \\
\hline Methabenzthiazuron & Tribunil $700 \mathrm{~g} / \mathrm{kg}$ & & & $1.75 \mathrm{~kg} / \mathrm{ha}$ & \\
\hline Clay & & 28.5 .1987 & 2.6 .1987 & & 3.9 \\
\hline Finesand & & 25.5 .1987 & 28.5 .1987 & & 3.5 \\
\hline Peat & & 28.5 .1987 & 2.6 .1987 & & 8.8 \\
\hline Metazachlor & Butisan S $500 \mathrm{~g} / 1$ & & & $1.0 \mathrm{~kg} / \mathrm{ha}$ & \\
\hline Clay & & & 24.6.1985 & & 2.2 \\
\hline Finesand & & & 24.6 .1985 & & 2.0 \\
\hline Mud clay & & & 18.6 .1985 & & 2.2 \\
\hline Trifluralin & Super Treflan $480 \mathrm{~g} / 1$ & & & $0.96 \mathrm{~kg} / \mathrm{ha}$ & \\
\hline Clay & & 2.6 .1987 & 2.6 .1987 & & 2.1 \\
\hline Finesand & & 25.5 .1987 & 25.5 .1987 & & 1.9 \\
\hline Peat & & 1.6 .1987 & 28.5 .1987 & & 4.8 \\
\hline Iprodione & Rovral-neste $250 \mathrm{~g} / 1$ & & & $0.75 \mathrm{~kg} / \mathrm{ha}$ & \\
\hline Clay & & 23.5 .1986 & 21.7 .1986 & & 1.7 \\
\hline Finesand & & 23.5 .1986 & 21.7 .1986 & & 1.5 \\
\hline Humus & & 23.5 .1986 & 21.7 .1986 & & 2.5 \\
\hline Fenitrothion & Folition $500 \mathrm{~g} / 1$ & & & $0.50 \mathrm{~kg} / \mathrm{ha}$ & \\
\hline Clay & & 20.5 .1988 & 1.7 .1988 & & 1.1 \\
\hline Finesand & & 20.5 .1988 & 1.7 .1988 & & 1.0 \\
\hline Humus & & 20.5 .1988 & 1.7 .1988 & & 1.7 \\
\hline Fenvalerate & Sumicidin $100 \mathrm{~g} / 1$ & & & $0.1 \mathrm{~kg} / \mathrm{ha}$ & \\
\hline Clay & & 4.6 .1986 & 8.7 .1986 & & 0.22 \\
\hline Finesand & & 4.6 .1986 & 8.7 .1986 & & 0.20 \\
\hline Humus & & 4.6 .1986 & 8.7 .1986 & & 0.33 \\
\hline Furathiocarb & Seeds pelleted with & & & $8.0 \mathrm{~g} / \mathrm{kg}$ seeds & \\
\hline Clay & Rypcol 40 DS $400 \mathrm{~g} / \mathrm{kg}$ & 20.5 .1988 & & & 0.18 \\
\hline Finesand & & 20.5 .1988 & & & 0.16 \\
\hline Humus & & 20.5 .1988 & & & 0.28 \\
\hline
\end{tabular}


Table 3. Mean monthly temperatures $\left({ }^{\circ} \mathrm{C}\right)$ and rainfall $(\mathrm{mm})$ during the pesticide studies in Jokioinen during the years $1985-1988$ and the average long term means from the years 1931 - 1960. Data was obtained from the Jokioinen observatory (Månadsöversikt... 1985-1988).

Years 1931-1960 May June July August September

$\begin{array}{lrrrrr}\text { Mean temperature } & 8.8 & 13.7 & 16.2 & 14.7 & 9.7 \\ \text { Rainfall } & 39 & 42 & 70 & 74 & 61\end{array}$

Year 1985

$\begin{array}{lrrrrr}\text { Mean temperature } & 8.4 & 13.2 & 15.3 & 15.5 & 8.9 \\ \text { Rainfall } & 43 & 41.4 & 55.4 & 119.2 & 51.3\end{array}$

Year 1986

$\begin{array}{rrrrrr}\text { Mean temperature } & 10.8 & 16.3 & 16.2 & 12.9 & 6.4\end{array}$

$\begin{array}{llllll}\text { Rainfall } & 52 & 11 & 64.9 & 109.8 & 102.4\end{array}$

Year 1987

$\begin{array}{lrrrrr}\text { Mean temperature } & 7.6 & 12.1 & 14.8 & 11.7 & 8.4 \\ \text { Rainfall } & 37.5 & 81.3 & 67.5 & 82.9 & 119.9\end{array}$

Year 1988

$\begin{array}{llllll}\text { Mean temperature } & 11.4 & 16.5 & 19.0 & 14.1 & 10.8\end{array}$

$\begin{array}{llllll}\text { Rainfall } & 43.5 & 24.8 & 127.7 & 79.3 & 85.1\end{array}$

15 - $25 \mathrm{~cm}$ deep. 4 - 5 subsamples were taken from each layer by a simple random sampling using a shovel and taking samples with the same surface area. In the finesand soils, samples were taken with the help of a metal frame to avoid flowing of the soil. In the metazachlor study only one composite sample $0-5 \mathrm{~cm}$ deep was taken one day after the treatment. The $0.5-1$ liter $(0.5-1 \mathrm{~kg})$ subsamples were mixed and homogenized, each soil layer in its own vessel. Finally a composite sample of c. $1 \mathrm{~kg}$ was extracted in a plastic bag and frozen.

The chemical analysis of the pesticides were made at the State Institute of Agricultural Chemistry according to the methods described in Table 4. The analysis were generally made on moist soil samples. The results were calculated using dry weight which was determined after drying in $105{ }^{\circ} \mathrm{C}$ for four hours. The samples from the control plots were used as blanks in order to eliminate the effects of interfering compounds. These samples were also used to obtain a standard curve with a standard addition method. The results are expressed as a mean of two parallel determinations.

Table 4. The gas chromatographic analysis methods used by the State Institute of Agricultural Chemistry for the studied pesticides and their degradation products. Some details of the analysis may have been slightly different from the referred methods. The determination limits for the organic soils are presented in parenthesis.

\begin{tabular}{|c|c|c|c|c|}
\hline $\begin{array}{l}\text { Pesticide/transfor- } \\
\text { mation product }\end{array}$ & Solvent & Detector & $\begin{array}{l}\text { Determination } \\
\text { limit }(\mathrm{mg} / \mathrm{kg})\end{array}$ & Reference \\
\hline Methabenzthiazuron & $\begin{array}{l}\text { acetone- } \\
\text { dichloromethane }\end{array}$ & $\begin{array}{l}\text { nitrogen-phosphorus } \\
\text { detector }\end{array}$ & $0.005(0.02)$ & JARCZYK 1972 \\
\hline Metazachlor & methanol & $\begin{array}{l}\text { electron capture } \\
\text { detector }\end{array}$ & 0.002 & Determination by... 1978 \\
\hline Trifluralin & $\begin{array}{l}\text { methanol/ } \\
\text { acetone }\end{array}$ & $\begin{array}{l}\text { electron capture } \\
\text { detector }\end{array}$ & $0.005(0.01)$ & $\begin{array}{l}\text { TePE \& SCRoggs } 1967, \\
\text { LEE \& CHAU } 1983\end{array}$ \\
\hline $\begin{array}{l}\text { Iprodione/ } \\
\text { RP-30228 }\end{array}$ & acetone & $\begin{array}{l}\text { electron capture } \\
\text { detector }\end{array}$ & $\begin{array}{l}0.005(0.02) \\
\text { finesand:0.003 } \\
\text { RP-30228: } 0.05(0.1)\end{array}$ & $\begin{array}{l}\text { Determination of... 1985, } \\
\text { WALKER et al. } 1986\end{array}$ \\
\hline Fenitrothion/ & dichloromethane- & nitrogen-phosphorus/ & 0.005 & ТАКIMOTO \& \\
\hline 3-methyl-4-nitrophenol & acetone & electron capture detector & $0.02(0.05)$ & МічАмОто 1976 \\
\hline Fenvalerate & hexane-acetone & $\begin{array}{l}\text { electron capture } \\
\text { detector }\end{array}$ & $\begin{array}{l}0.02(0.03) \\
\text { finesand: } 0.01\end{array}$ & HILL 1981 \\
\hline $\begin{array}{l}\text { Furathiocarb/ } \\
\text { carbofuran }\end{array}$ & methanol & $\begin{array}{l}\text { mass selective } \\
\text { detector }\end{array}$ & $\begin{array}{l}0.01(0.04) \\
0.005 \text {; finesand: } 0.01\end{array}$ & Gas chromatographic... 1983 \\
\hline
\end{tabular}


Table 5. The disappearance times and the concentrations of the pesticides (c) and their degradation products in the different layers of the studied soils at the sampling times (indicated in parenthesis as days after the pesticide treatment). $T_{50}$ is the halflife of concentration of the compound at the sampling time, given in days. The concentrations are calculated as mg/kg for dry weight. n.d. indicates a value under the determination limit or that the result could not be calculated, and an asterisk ( $\left.{ }^{*}\right)$ a missing value. Exceptional sampling times are given in parenthesis following the results.

\section{Methabenzthiazuron}

Soil type

Clay soil

$\begin{array}{llllll}0-5 \mathrm{~cm} & 3.0 & 21 & 0.95 & 180 & 0.42 \\ 5-15 \mathrm{~cm} & \text { n.d. } & \text { n.d. } & 0.007 & \text { n.d. } & 0.015 \\ 15-25 \mathrm{~cm} & \text { n.d. } & \text { n.d. } & \text { n.d. } & \text { n.d. } & 0.006\end{array}$

Finesand soil

$\begin{array}{llllll}0-5 \mathrm{~cm} & 1.6 & 23 & 0.60 & \infty & 0.60 \\ 5-15 \mathrm{~cm} & 0.03 & \text { n.d. } & 0.13 & \text { n.d. } & \text { n.d. } \\ 15-25 \mathrm{~cm} & 0.01 & \text { n.d. } & 0.07 & \text { n.d. } & \text { n.d. } \\ \text { soil } & & & (32 \mathrm{~d}) & (32 \mathrm{~d}) & (140 \mathrm{~d}) \\ 0-5 \mathrm{~cm} & 2.7 & \text { n.d. } & 3.2 & 57 & 0.19 \\ 5-15 \mathrm{~cm} & 0.04 & \text { n.d. } & 0.04 & \text { n.d. } & \text { n.d. } \\ 15-25 \mathrm{~cm} & 0.11 & \text { n.d. } & \text { n.d. } & \text { n.d. } & \text { n.d. }\end{array}$

\section{Metazachlor}

\begin{tabular}{clllll} 
Soil type & $\mathrm{c}(1 \mathrm{~d})$ & $\mathrm{T}_{50}(1 \mathrm{~d})$ & $\mathrm{c}(31 \mathrm{~d})$ & $\mathrm{T}_{50}(31 \mathrm{~d})$ & $\mathrm{c}(86 \mathrm{~d})$ \\
\hline Clay soil & & & & & \\
$0-5 \mathrm{~cm}$ & 0.46 & 29 & 0.22 & 36 & 0.05 \\
$5-15 \mathrm{~cm}$ & $*$ & $*$ & 0.01 & 46 & 0.004 \\
$15-25 \mathrm{~cm}$ & $*$ & $*$ & 0.01 & n.d. & n.d. \\
Finesand soil & & & & & \\
$0-5 \mathrm{~cm}$ & $* .30$ & 47 & 0.21 & 29 & 0.012 \\
$5-15 \mathrm{~cm}$ & $*$ & $*$ & 0.028 & n.d. & n.d. \\
$15-25 \mathrm{~cm}$ & & $*$ & 0.017 & n.d. & n.d. \\
Mud clay soil & & & $(30 \mathrm{~d})$ & $(30 \mathrm{~d})$ & $(92 \mathrm{~d})$ \\
$0-5 \mathrm{~cm}$ & $* .55$ & 63 & 0.53 & 35 & 0.06 \\
$5-15 \mathrm{~cm}$ & $*$ & $*$ & 0.03 & 44 & 0.009 \\
$15-25 \mathrm{~cm}$ & $*$ & $*$ & 0.05 & 32 & 0.002
\end{tabular}

\section{Trifluralin}

\begin{tabular}{|c|c|c|c|c|c|c|c|}
\hline Soil type & $c(1 \mathrm{~d})$ & $\mathrm{T}_{50}(1 \mathrm{~d})$ & $c(32 d)$ & $T_{50}(32 d)$ & $c(140 d)$ & & \\
\hline Clay soil & & & $(30 \mathrm{~d})$ & $(30 \mathrm{~d})$ & (132 d) & & \\
\hline $0-5 \mathrm{~cm}$ & 2.7 & 280 & 2.1 & 310 & 1.8 & & \\
\hline $5-15 \mathrm{~cm}$ & 0.05 & n.d. & 0.10 & 85 & 0.04 & & \\
\hline $15-25 \mathrm{~cm}$ & 0.04 & n.d. & 0.005 & n.d. & 0.01 & & \\
\hline \multicolumn{8}{|l|}{ Finesand soil } \\
\hline $0-5 \mathrm{~cm}$ & 1.6 & 210 & 1.3 & 234 & 1.0 & & \\
\hline $5-15 \mathrm{~cm}$ & 0.07 & 46 & 0.04 & 62 & 0.005 & & \\
\hline $15-25 \mathrm{~cm}$ & 0.005 & $\infty$ & 0.005 & n.d. & n.d. & & \\
\hline Peat soil & & & & & & $T_{s_{0}}(140 \mathrm{~d})$ & $c(466 d)$ \\
\hline $0-5 \mathrm{~cm}$ & 7.0 & 220 & 6.3 & 250 & 4.0 & 340 & 2.1 \\
\hline $5-15 \mathrm{~cm}$ & 0.09 & n.d. & 0.77 & 58 & 0.05 & 410 & 0.03 \\
\hline $15-25 \mathrm{~cm}$ & 0.08 & 21 & 0.02 & n.d. & 0.06 & 200 & 0.01 \\
\hline
\end{tabular}




\section{Iprodione}

\begin{tabular}{lcccrr} 
Soil type & $c(1 \mathrm{~d})$ & $\mathrm{T}_{50}(1 \mathrm{~d})$ & $\mathrm{c}(32 \mathrm{~d})$ & $\mathrm{T}_{50}(32 \mathrm{~d})$ & $\mathrm{c}(64 \mathrm{~d})$ \\
\hline Clay soil & & & & & \\
$0-5 \mathrm{~cm}$ & 0.06 & n.d. & 0.35 & n.d. & 0.40 \\
$5-15 \mathrm{~cm}$ & n.d. & n.d. & 0.03 & 32 & 0.005 \\
$15-25 \mathrm{~cm}$ & n.d. & n.d. & n.d. & n.d. & n.d.
\end{tabular}

Finesand soil: for concentrations, see Fig. 4

Humus soil

$\begin{array}{lrlrlr}0-5 \mathrm{~cm} & 0.04 & \text { n.d. } & 0.30 & \text { n.d. } & 0.60 \\ 5-15 \mathrm{~cm} & \text { n.d. } & \text { n.d. } & \text { n.d. } & \text { n.d. } & \text { n.d. } \\ 15-25 \mathrm{~cm} & \text { n.d. } & \text { n.d. } & \text { n.d. } & \text { n.d. } & \text { n.d. }\end{array}$

RP-30228 (degradation product of iprodione)

\begin{tabular}{lccccc} 
Soil type & $\mathrm{c}(1 \mathrm{~d})$ & $\mathrm{T}_{50}(1 \mathrm{~d})$ & $\mathrm{c}(32 \mathrm{~d})$ & $\mathrm{T}_{50}(32 \mathrm{~d})$ & $\mathrm{c}(64 \mathrm{~d})$ \\
\hline Clay soil & & & & & \\
$0-5 \mathrm{~cm}$ & n.d. & n.d. & 0.20 & $\infty$ & 0.20 \\
$5-15 \mathrm{~cm}$ & n.d. & n.d. & n.d. & n.d. & n.d. \\
$15-25 \mathrm{~cm}$ & n.d. & n.d. & n.d. & n.d. & n.d.
\end{tabular}

Finesand soil: for concentrations, see Fig. 4

Humus soil

$\begin{array}{llllrr}0-5 \mathrm{~cm} & \text { n.d. } & \text { n.d. } & 0.30 & 96 & 0.60 \\ 5-15 \mathrm{~cm} & \text { n.d. } & \text { n.d. } & \text { n.d. } & \text { n.d. } & \text { n.d. } \\ 15-25 \mathrm{~cm} & \text { n.d. } & \text { n.d. } & \text { n.d. } & \text { n.d. } & \text { n.d. }\end{array}$

Fenitrothion and 3-methyl-4-nitrophenol (degradation product of fenitrothion): for concentrations, see Fig. 5

Fenvalerate: for concentrations, see Fig. 6

Furathiocarb: for concentrations, see Fig. 7

Carbofuran (degradation product of furathiocarb): for concentrations, see Fig. 7

Soil type

Clay soil

$$
\begin{aligned}
& 0-5 \mathrm{~cm} \\
& 5-15 \mathrm{~cm}
\end{aligned}
$$

30
n.d.

n.d.

n.d.

Humus soil

$\begin{array}{lrl}0-5 \mathrm{~cm} & 60 & \text { n.d. } \\ 5-15 \mathrm{~cm} & \infty & \text { n.d. }\end{array}$

In the finesand soil and in all $15-25 \mathrm{~cm}$ layers no residues were found. 


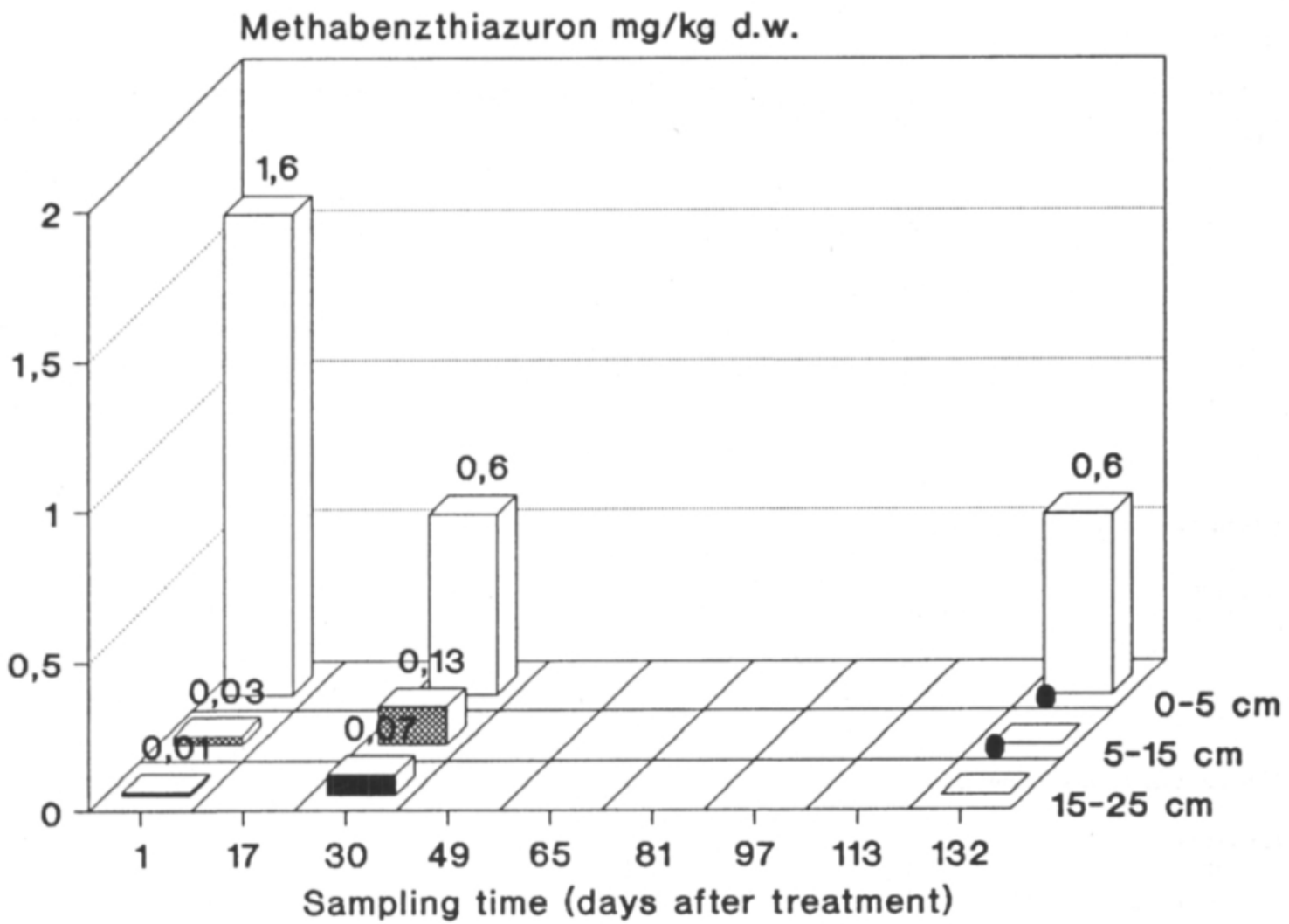

Fig. 1. The concentration of methabenzthiazuron $(\mathrm{mg} / \mathrm{kg} \mathrm{dw})$ in the finesand soil during the growing season 1987. A point $(\cdot)$ indicates a value below the determination limit.

\section{Results and discussion}

The results are presented as $\mathrm{mg} / \mathrm{kg}$, and also as $\mathrm{mg} / \mathrm{dm}^{3}$. The amount of pesticide distributed per unit area was the same in all plots and consequently their concentrations in different soil types were comparable when calculated per unit volume (KURKI et al. 1965). This was done by using the following densities of the soils: clay 0.9 , finesand 1.0 , humus 0.6 , and peat $0.4 \mathrm{~kg} / \mathrm{dm}^{3}$. This effectively eliminated errors due to the fact that the lighter peat soils have a greater surface area per weight unit and therefore higher concentrations of pesticides per unit weight than the mineral soils. The sampling times, the disappearance times and the concentrations of the pesticides and their degradation products in the soil samples are shown in Table 5.

A day after the treatment residues of the pesticides were detected at depths greater than $5 \mathrm{~cm}$ in the soils. This may be due to extremely quick leaching in finesand soils or transportation through cracks in clay soils, or also to contamination of the samples from the overlying soil layers.

\section{Methabenzthiazuron}

Methabenzthiazuron was hardly mobile at all in the clay soil. The highest concentration of methabenzthiazuron in the clay soil, $77 \%$ of the calculated maximum initial concentration, was determined one day after the treatment. After that the concentration decreased rapidly. In the finesand 
soil methabenzthiazuron was rather mobile (Fig. 1): the leaching was at least $15 \mathrm{~cm}$ a month. The amount of methabenzthiazuron of the surface of the finesand soil decreased quickly in the beginning, but later this disappearance was almost stopped. The highest concentration in the finesand soil was $46 \%$ of the calculated maximum initial concentration one day after the treatment. In the peat soil surface layer the contents of methabenzthiazuron increased during the first month after the treatment up to $36 \%$ of the calculated maximum initial concentration. The increase of the contents of methabenzthiazuron in the peat soil during the month after the treatment may have been due to leaching from the onions.

In this study methabenzthiazuron was most mobile in the finesand soil. PESTEMER (1977) has also found that the absorption of methabenzthiazuron increases with increasing humus content of a soil. KUBIAK et al. (1988) have noticed in their lysimeter study that methabenzthiazuron leached in a neutral clay loess soil less than in this study. Furthermore, in a laboratory study of BRUMHARD et al. (1988) methabenzthiazuron leached in a slightly acid humic sand and in a degraded loess soil at 21 ${ }^{\circ} \mathrm{C}$ much less than in this study. But, on the other hand, BRUMHARD et al. (1988) state that, according to the results of their outdoor lysimeter studies with the same soil type, the contamination of the groundwater by small amounts of methabenzthiazuron residues cannot be excluded.

The disappearance rate of methabenzthiazuron in this study was similar to that found by KUBIAK et al. (1988) in their field studies. On the other hand PESTEMER and Auspurg (1987) in their field study on a sandy soil in Germany obtained a half-life for methabenzthiazuron longer than that of this study. PESTEMER (1988) detected after repeated application of methabenzthiazuron to the soil over several years a greater concentration of residues than in this study. The degradation of methabenzthiazuron is temperature dependent. FÜHR and MitTELSTAEDT (1979) observed in a degraded loess soil that a drop in temperature from $20^{\circ} \mathrm{C}$ to $10^{\circ} \mathrm{C}$ reduced the degradation rate by one third and at 0
${ }^{\circ} \mathrm{C}$ the degradation stopped. Thus in this study some of the residues of methabenzthiazuron found in the autumn might have survived in the soil over the winter.

\section{Metazachlor}

Metazachlor leached at least $15 \mathrm{~cm}$ a month in all soil types. In the clay soil surface layer the disappearance of metazachlor slowed down after a month, but in the mud clay soil metazachlor initially vanished from the top soil slowly, the rate of its disappearance accelerated after a month (Fig. $2)$. In the finesand soil surface layer the disappearance time of metazachlor was about the same all the time. The highest detected top soil concentration of metazachlor was $21 \%$ of the calculated maximum initial concentration in the clay soil, $15 \%$ in the finesand soil and $25 \%$ in the mud clay soil.

Metazachlor was more mobile in this study than in the field experiments of RouCHAUD et al. (1989) in sandy and silty soils. On the other hand KREUGER and BRINK (1988) found metazachlor residues in Swedish river water samples near areas used for agricultural production. The rates of disappearance of metazachlor in this study were similar to those observed by NiLSSON (1985) in Swedish field experiments and by Rouchaud et al. (1989) in Belgian field studies. In the British field studies of WALKER and BROWN (1985) the half life of metazachlor was as short as or shorter than in the clay soil of this study. As soil temperature and moisture affect the degradation of metazachlor (ALLEN and WALKER 1984) the disappearance of metazachlor in this study may have been accelerated in August 1985, when it rained heavily but the temperature was normal.

\section{Trifluralin}

Although trifluralin leached more than $15 \mathrm{~cm}$ a month in all soil types, the amounts leached were small. Trifluralin disappeared from the surface soils studied so slowly that its half life was longer 


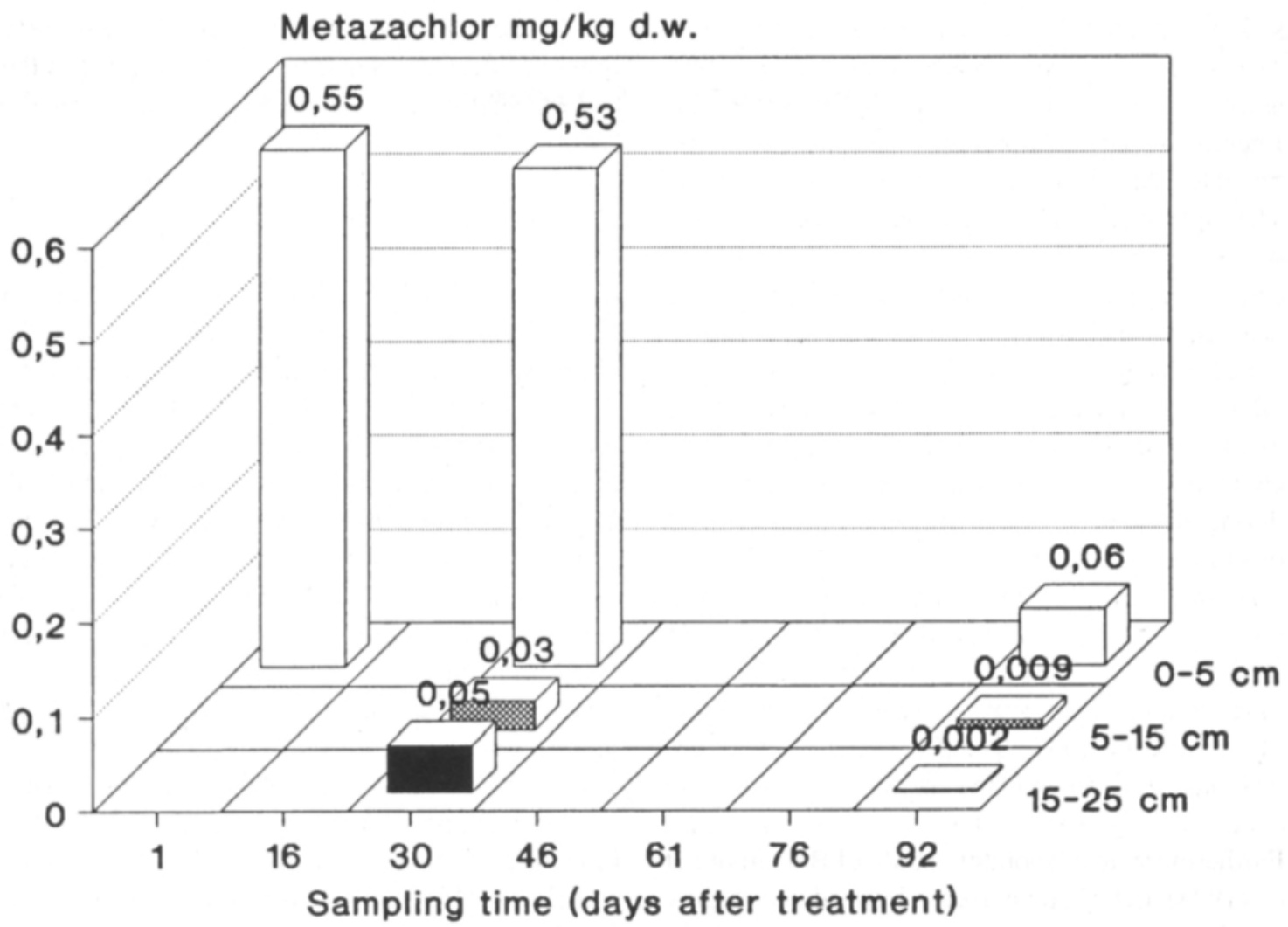

Fig. 2. The concentration of metazachlor $(\mathrm{mg} / \mathrm{kg} \mathrm{dw})$ in the mud clay soil during the growing season 1985 .

than the growing season. The contents of trifluralin decreased slower below $5 \mathrm{~cm}$ than in the surface layer. Only in the peat soil plot was the study period long enough to allow the half-life of trifluralin to be calculated. Trifluralin disappeared quite steadily during the first growing season. The disappearance rate in the peat soil slowed down during the next sampling period up to the end of the subsequent growing season (Fig. 3). The highest observed top soil concentration of trifluralin was $130 \%$ of the calculated maximum initial concentration in the clay soil, $84 \%$ in the finesand soil and $150 \%$ in the mud clay soil.

The mobility of trifluralin in the clay and finesand soils of this study was less than found by Duseja and Holmes (1978) in their field studies in clay and loam soils in the United States. Also
Helling (1971) has classified trifluralin as immobile on the grounds of his laboratory experiments. In this study only the contents of trifluralin in the $5-15 \mathrm{~cm}$ layer of the peat soil a month after the treatment was exceptionally high. The slow degradation of trifluralin has been observed also in many earlier studies, e.g. ProBst et al. (1967) and LAFLEUR et al. (1978) in field studies in the United States and HAYDEN and SMITH (1980), JENSEN and Kimball (1980) and Grover et al. (1988) in Canadian field studies. In the Canadian studies three stages in the degradation of trifluralin have been demonstrated as described by Grover et al. (1988). These are a quick disappearance during about the first week, a slow disappearance during the first growing season and a winter period with hardly any degradation. In this study no period of quick disap- 


\section{Trifluralin $\mathrm{mg} / \mathrm{kg}$ d.w.}

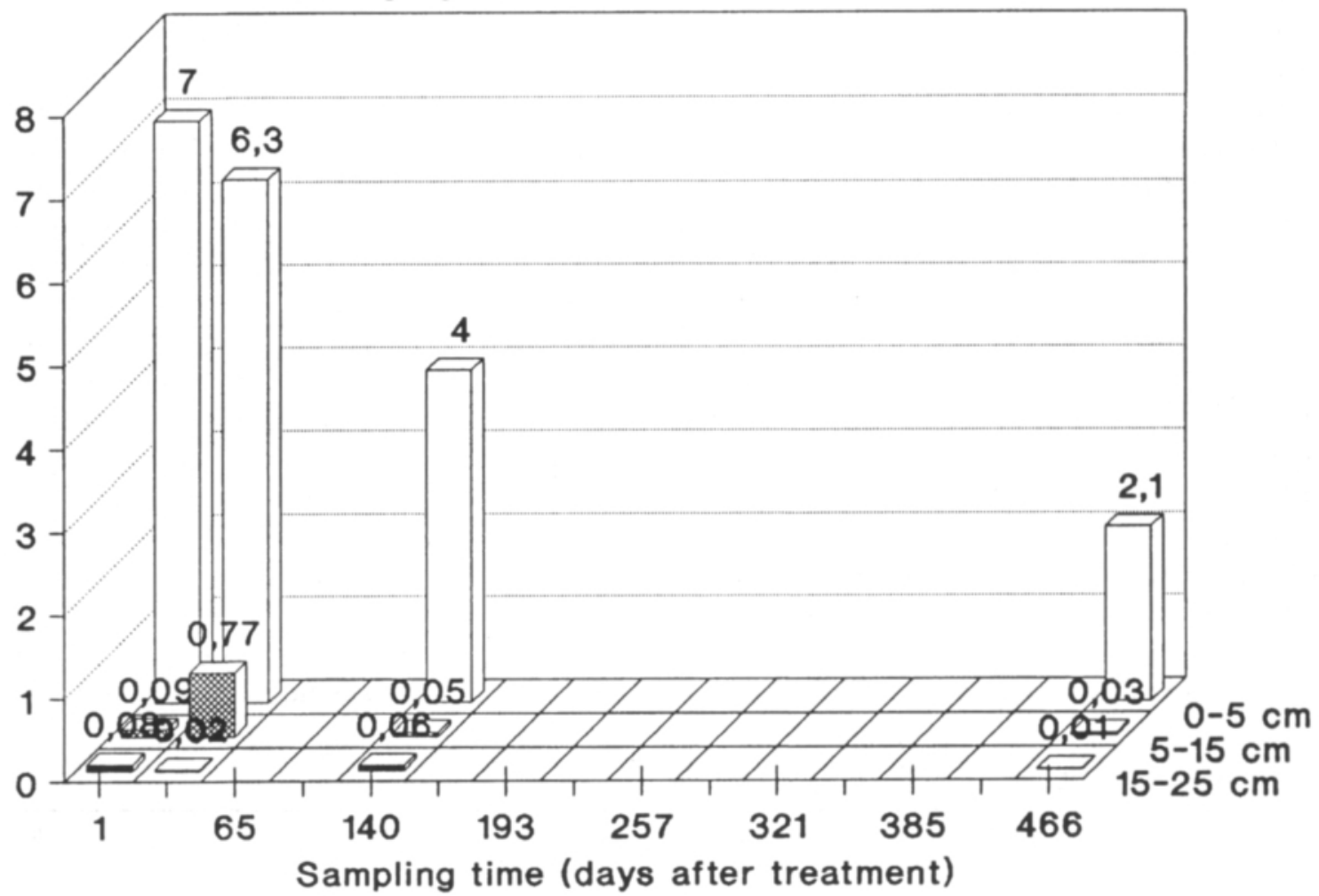

Fig. 3. The concentration of trifluralin $(\mathrm{mg} / \mathrm{kg} \mathrm{dw})$ in the peat soil during the growing season 1987.

pearance at the beginning was observed.

The degradation of trifluralin is reduced in dry and cold conditions (JACQUES and HARVEY 1979). The weather during the study period of 1987 was exceptionally cold and rainy, therefore the disappearance of trifluralin may have been unusual. On the basis of the study of DusEJA and Holmes (1978) the concentrations of trifluralin in the surface layers of all the soils of this study at the end of the first growing season might have retarded the growth of oat sprouts over $60 \%$. In the peat soil the concentration of trifluralin was at a harmful level also at the end of the second growing season. But, on the other hand, trifluralin is strongly deactivated by organic material and it is not used in organic soils. However, this problem of phytotoxicity should be examined more precisely in different mineral soils in Finnish climatic conditions.

\section{Iprodione}

Both iprodione and its degradation product RP-30228 were most mobile in the finesand soil. The concentration of iprodione increased in all the soil types during the study period. The highest contents of iprodione was $24 \%$ of the calculated maximum initial concentration at the end of the growing season both in the clay and humus soils. In the finesand soil the highest contents was $20 \%$ of the calculated maximum initial concentration as early as a month after the treatment. The degradation product RP-30228 acted similarly to iprodione. Nevertheless the highest contents of RP30228 were detected earlier than those of iprodione. In the clay soil iprodione disappeared from the $5-15 \mathrm{~cm}$ soil layer quicker than from the surface layer. In the clay soil RP-30228 was 
discovered only in the surface layer, from which it disappeared faster than iprodione. In contrast, in the finesand soil the contents of iprodione and RP30228 increased towards autumn also in the 5-15 $\mathrm{cm}$ layer and thus leaching of the compounds was greater than their disappearance (Fig. 4). In the finesand soil iprodione was also observed at depths between 15 and $25 \mathrm{~cm}$. Both iprodione and RP30228 were relative immobile in the humus soil: they were not detected deeper than $5 \mathrm{~cm}$. Furthermore, at the end of the growing season in the humus soil surface layer RP-30228 vanished quicker than iprodione was transformed into RP-30228.

The elevation of the contents of iprodione during almost all the study period in all the soils is apparently due to leaching of the compound from vegetation. In the studied soils iprodione leached much less than in the sandy and silty soils in the laboratory study of ELMER and STIPES $(1981,1985)$. They also found that the disappearance of iprodione was slower at a lower temperature. Thus residues of iprodione in this study could have remained in the soils over the following winter. Moreover degradation of iprodione is enhanced when it is used repeatedly in the same field plot, and on the other hand, degradation is decreased in very acid soils (WALKER et al. 1984, 1986, WALKER 1987 b, HEAD et al. 1988). But as iprodione had not been used in these study plots for at least the four previous years and the soils were almost neutral, the degradation rate of iprodione should have not been altered for these reasons.

\section{Fenitrothion}

No residues of fenitrothion or its degradation product 3-methyl-4-nitrophenol were observed in
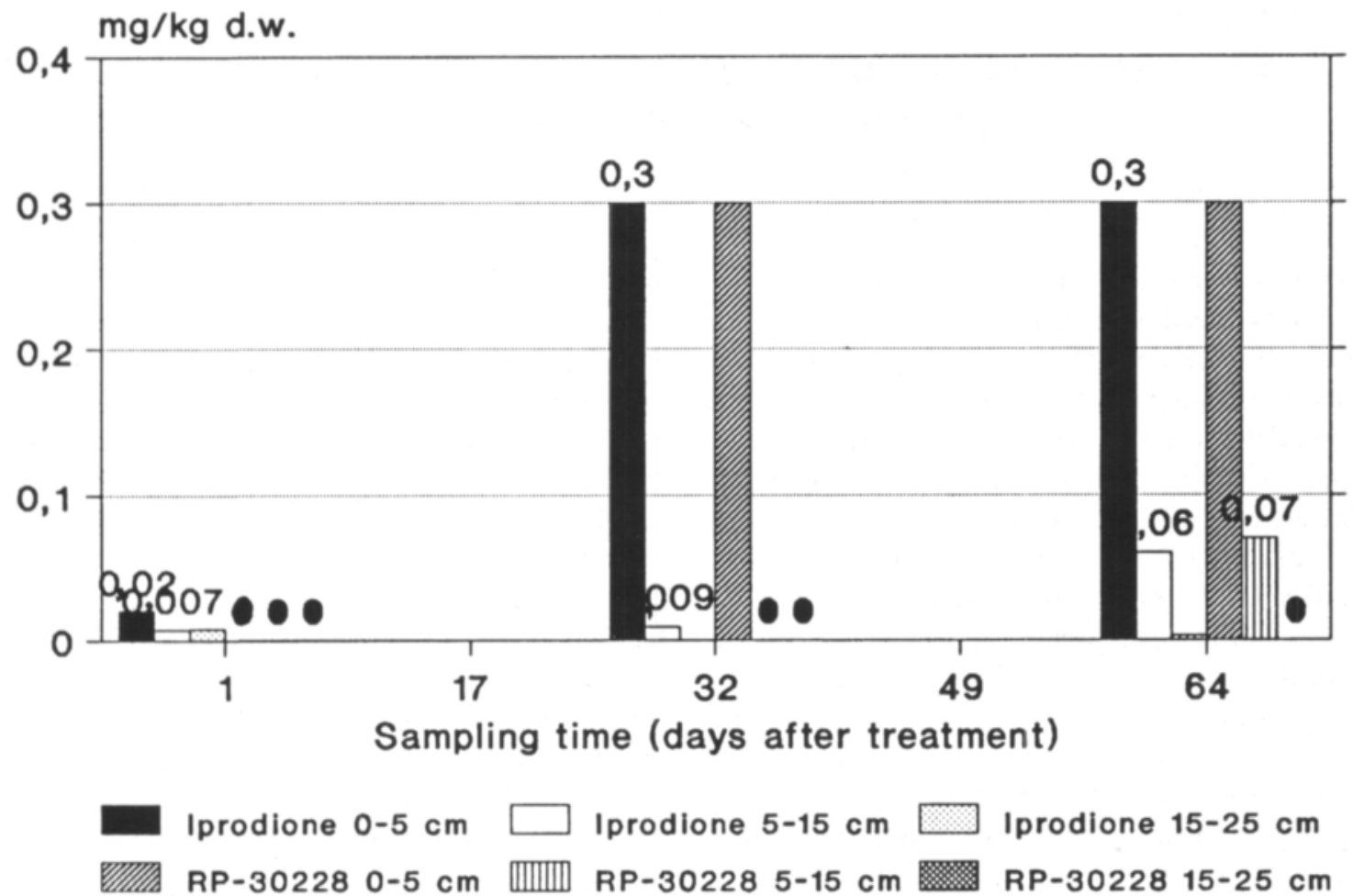

Fig. 4. The concentration of iprodione and its degradation product RP-30228 (mg/ kg dw) in the finesand soil during the growing season 1986. A point $(\bullet)$ indicates a value below the determination limit. 
the humus soil. Fenitrothion and 3-methyl-4nitrophenol also disappeared very quickly from the clay soil (Fig. 5). No residues of both of them were observed a month after the treatment. Either fenitrothion was retained in the surface soil or the residues which leached deeper also degraded in less than a month. The highest detected top soil concentration of fenitrothion a day after the treatment was $7.3 \%$ of the calculated maximum initial concentration in the clay soil. In the finesand soil the disappearance of fenitrothion and 3-methyl-4-nitrophenol was slower than in the other soils. Apart from that fenitrothion was leached $5-15 \mathrm{~cm}$ deep in a month or the degradation product was leached deeper from the surface layer.

The contents of organic material in a soil affects strongly the absorption of fenitrothion (BAARSCHERs et al. 1983, Sharma et al. 1985). BAARSCHERS et al. (1983) also observed that the adsorption of 3-methyl-4-nitrophenol in a soil is increased with increasing contents of organic material. They found, too, that the more watersoluble 3-methyl-4-nitrophenol is also more mobile than fenitrothion in neutral and acid soils. Thus probably because of the strong absorption in organic material no residues of fenitrothion or its degradation product were detected in the humus soil and fenitrothion was also not leached in the clay soil in this study. Also it seems that it was probably 3-methyl-4-nitrophenol and not fenitrothion that might have leached in the finesand soil of this study. On the other hand
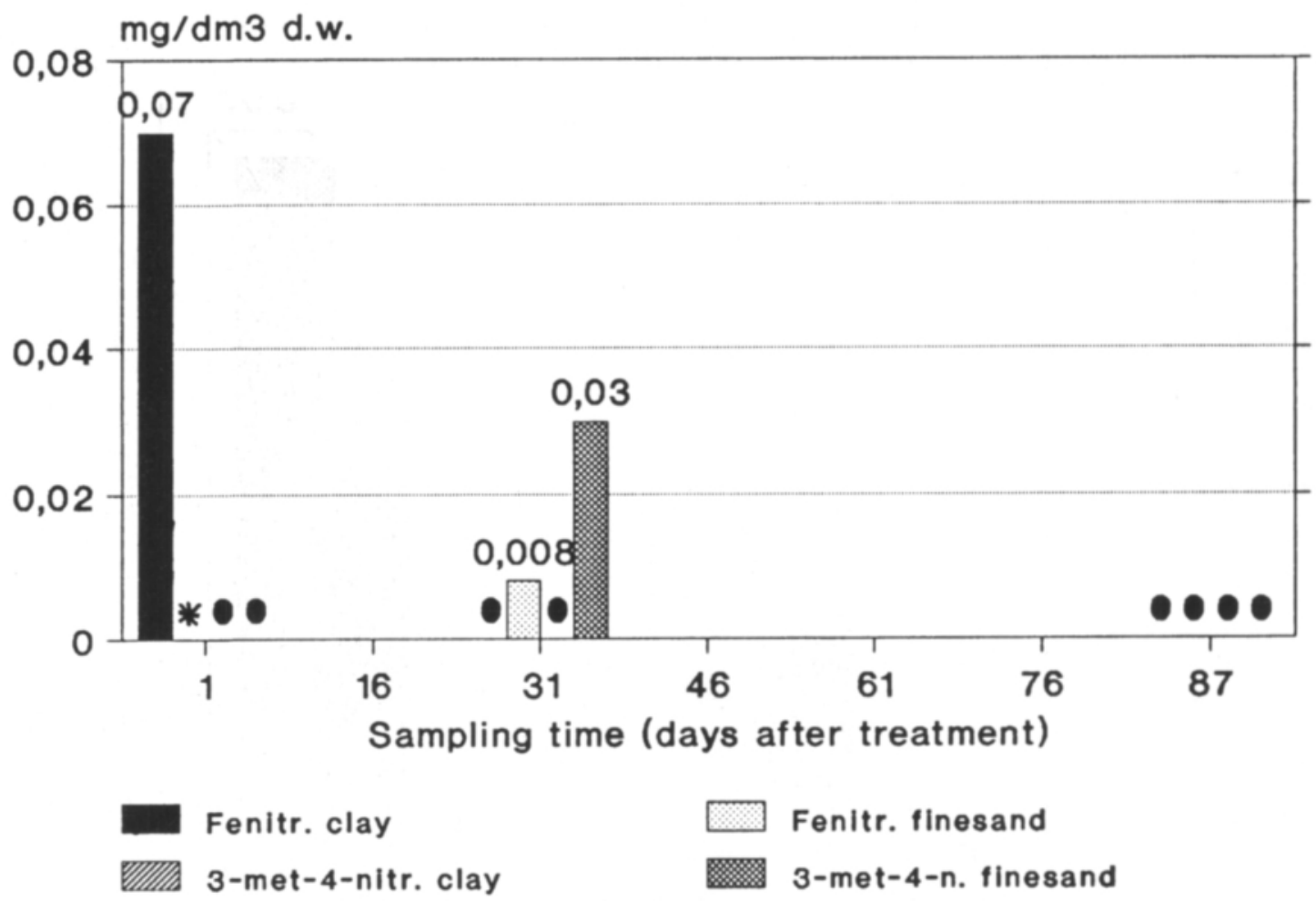

\section{Fenitr. finesand}

3-met-4-n. finesand

Fig. 5. The concentration of fenitrothion and its degradation product 3-methyl-4-nitrophenol $\left(\mathrm{mg} / \mathrm{dm}^{3} \mathrm{dw}\right)$ in the $0-5 \mathrm{~cm}$ layer of the clay and finesand soils during the growing season 1988. The compounds were not detected in the humus soil. A point $(\cdot)$ indicates a value below the determination limit and an asterisk $\left({ }^{*}\right)$ a missing value. 
Kreuger (1986) and Kreuger and BrinK (1988) found fenitrothion residues in Swedish river water samples near cultivated areas. ТАКімото et al. (1976) noticed in their laboratory studies at $25^{\circ} \mathrm{C}$ that fenitrothion was leached to a great extent only in sandy soils and that its half-life was 12-28 days. MiKami et al. (1985) found that the half-lives of fenitrothion and 3-methyl-4-nitrophenol were shorter than seven days in similar conditions. These results give support for the rapid degradation of fenitrothion observed in the Finnish field conditions. Furthermore the degradation of fenitrothion may have been accelerated, as during this study period in July 1988 it rained heavily, and according to ALY et al. (1986) the degradation of fenitrothion is reduced by low soil moisture.

\section{Fenvalerate}

In the clay and finesand soils fenvalerate was immobile. In the humus soil no residues were detected at all. In the clay and finesand soils the contents of fenvalerate increased during the study period (Fig. 6). More residues were discovered in the clay soil than in the finesand soil: the highest observed top soil concentration of fenvalerate was $36 \%$ of the calculated maximum initial concentration in the clay soil and $20 \%$ in the finesand soil.

Fenvalerate is almost immobile in the soil (e.g. HILL 1981), in agreement with what was observed also in this study. The concentration of fenvalerate in the clay and finesand soils of this study increased

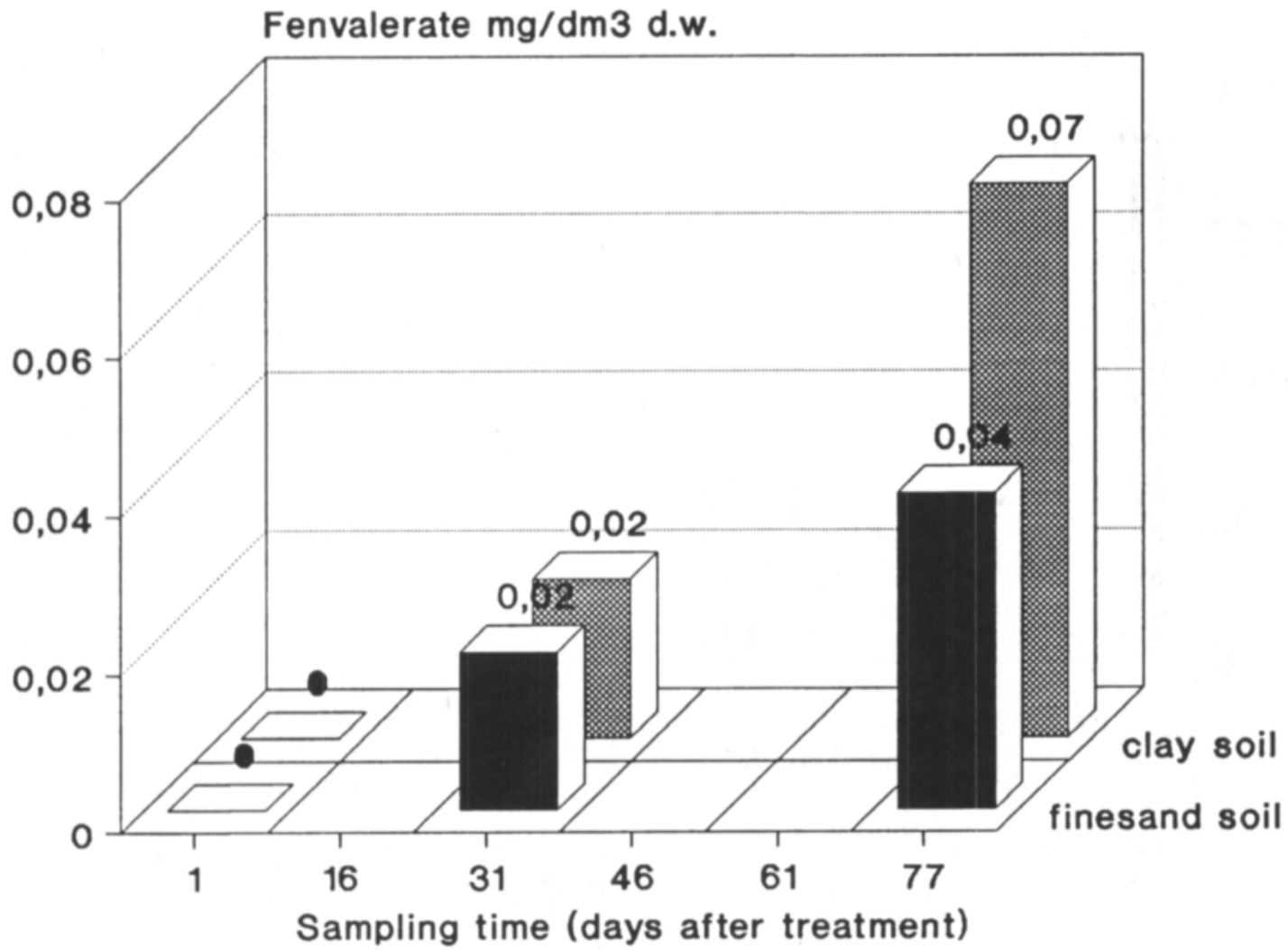

Fig. 6. The concentration of fenvalerate $\left(\mathrm{mg} / \mathrm{dm}^{3} \mathrm{dw}\right)$ in the $0-5 \mathrm{~cm}$ layer of the clay and finesand soils during the growing season 1986. The compound was not detected in the humus soil. A point $(\bullet)$ indicates a value below the determination limit. 
during the study period, presumably because it was leached from vegetation to soil. The amount of fenvalerate that leaches from the plants is more dependent on the total volume of rainfall than on its intensity (MCDowell 1987). Thus also in this study fenvalerate was leached steadily during the summer as the amount of total rainfall increased. The leaching from the plants may have been quicker than normal because of the rainy end of summer 1986.

HILL (1981) found the half-life of fenvalerate in a sandy clay loam to be 42 days in the field and 36 days in the laboratory. In a Japanese study (Miкамі 1987) the half-life at $25^{\circ} \mathrm{C}$ was 29 - 53 days in a light clay soil and 68 - 95 days in a sandy clay loam. Also BAHADIR et al. (1987) determined the half-life of fenvalerate as 88 days in a sandy clay loam at $22{ }^{\circ} \mathrm{C}$. In this study fenvalerate accumulated more in the clay soil than in the finesand soil, which indicates that the degradation of fenvalerate was slower in the clay soil. The contents of organic matter in a soil may affect the degradation, because fenvalerate is adsorbed in it (Williams and Brown 1979, Chapman et al. 1981, TAleKar et al. 1983). Degradation is also reduced in an acid, dry or cold soil (TALEKAR et al. 1983). Thus the exceptionally cold weather during the end of this study may have reduced the degradation of fenvalerate. On the other hand, no residues of fenvalerate were detected in the humus soil, so either it was very strongly adsorbed or it was quickly degraded. HILl (1981) observed in Canadian field experiments that the degradation of fenvalerate almost stopped during the winter and the next spring there were residues left ( $11 \%$ of the original amount) in the $0-2.5 \mathrm{~cm}$ soil layer. In his field study in California LEE (1985) found $35 \%$ of the fenvalerate remaining in loam soils a year after the treatment. Thus it seems that also in this study the fenvalerate residues detected in the autumn might have been still in the soil in the following spring. The residues would have been, nevertheless, rather insignificant for the next crop.

\section{Furathiocarb}

Furathiocarb and its degradation product carbofuran disappeared from all the soil types in less than four months (Fig. 7). In the finesand soil no residues were detected. The highest detected top soil concentration of furathiocarb in the clay soil was $11 \%$ of the calculated maximum initial concentration. In the clay soil furathiocarb leached faster than in the other soils. It was leached into the $5-15 \mathrm{~cm}$ layer in 2.5 months. It seems that furathiocarb was leached faster from the surface layer than it degraded. On the other hand carbofuran disappeared slower than furathiocarb from the surface layer of the clay soil. The results give no information about the mobility of carbofuran in the clay soil. In the humus soil no residues of furathiocarb were observed, but there was far more carbofuran in the surface layer than in the other soils. Moreover either one or both of the compounds leached to the $5-15 \mathrm{~cm}$ layer in 1.5 months. The concentration of carbofuran in the $5-15 \mathrm{~cm}$ layer of the humus soil remained the same during the $1.5-2.5$ months that followed sowing and disappeared in two months thereafter. This was slower than in the surface layer, in which carbofuran started to disappear 1.5 months after sowing. Thus furathiocarb degraded slower in the clay soil than in the other soils, but the disappearance rate of carbofuran was equal in the clay and humus soils.

There is little information about the mobility of furathiocarb. PUSSEMIER (1988) has stated that furathiocarb is much less mobile than its degradation product carbofuran, because, according to him it is less soluble in water and has a greater adsorbability. LiCHTENSTEIN and LiANG (1987) have also found carbofuran to be mobile in a silt loam and a sand soil in a laboratory experiment. According to FELSOT and WILSON (1980), the less organic material and clay there is in the soil the more mobile carbofuran is. On the other hand, a low soil temperature and acidity reduce the mobility of carbofuran (SINGH et al. 1987). PUSSEMIER (1988) concluded that carbofuran rather 
Fig. 7.1

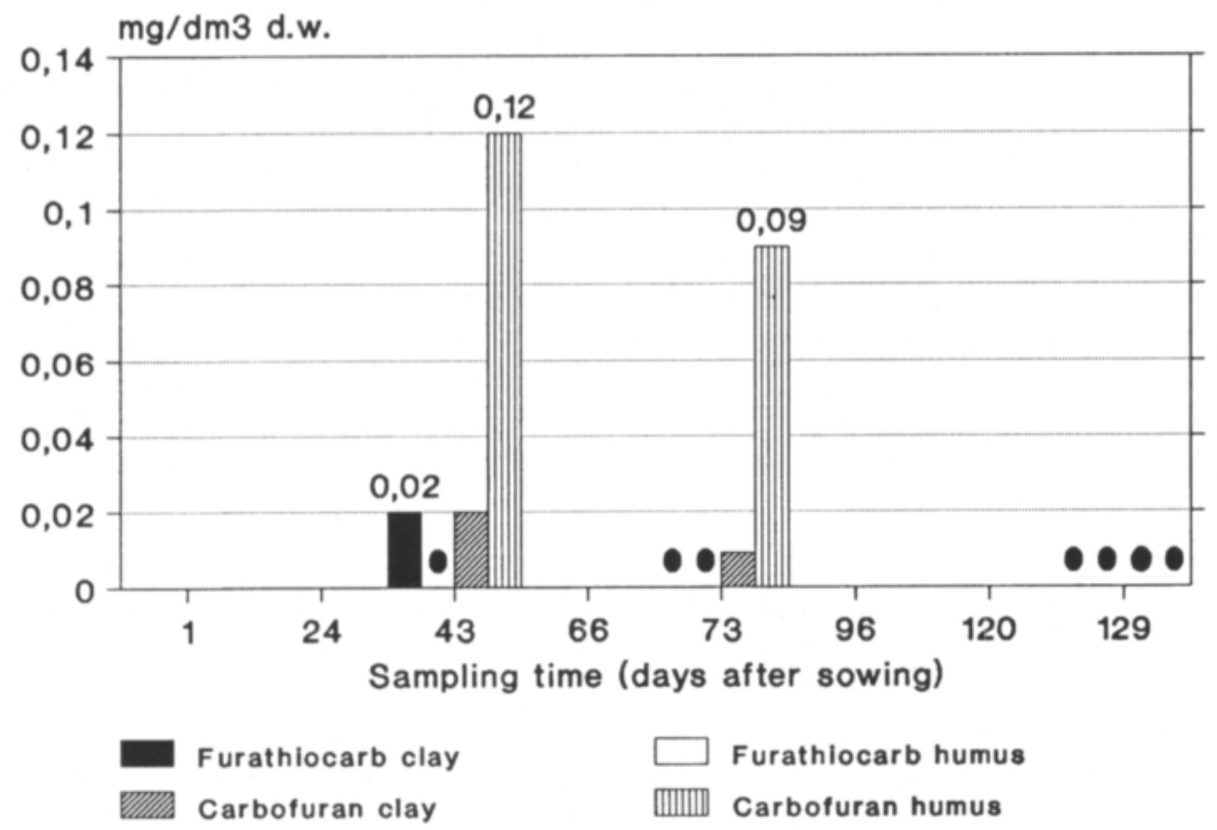

Fig. 7.2

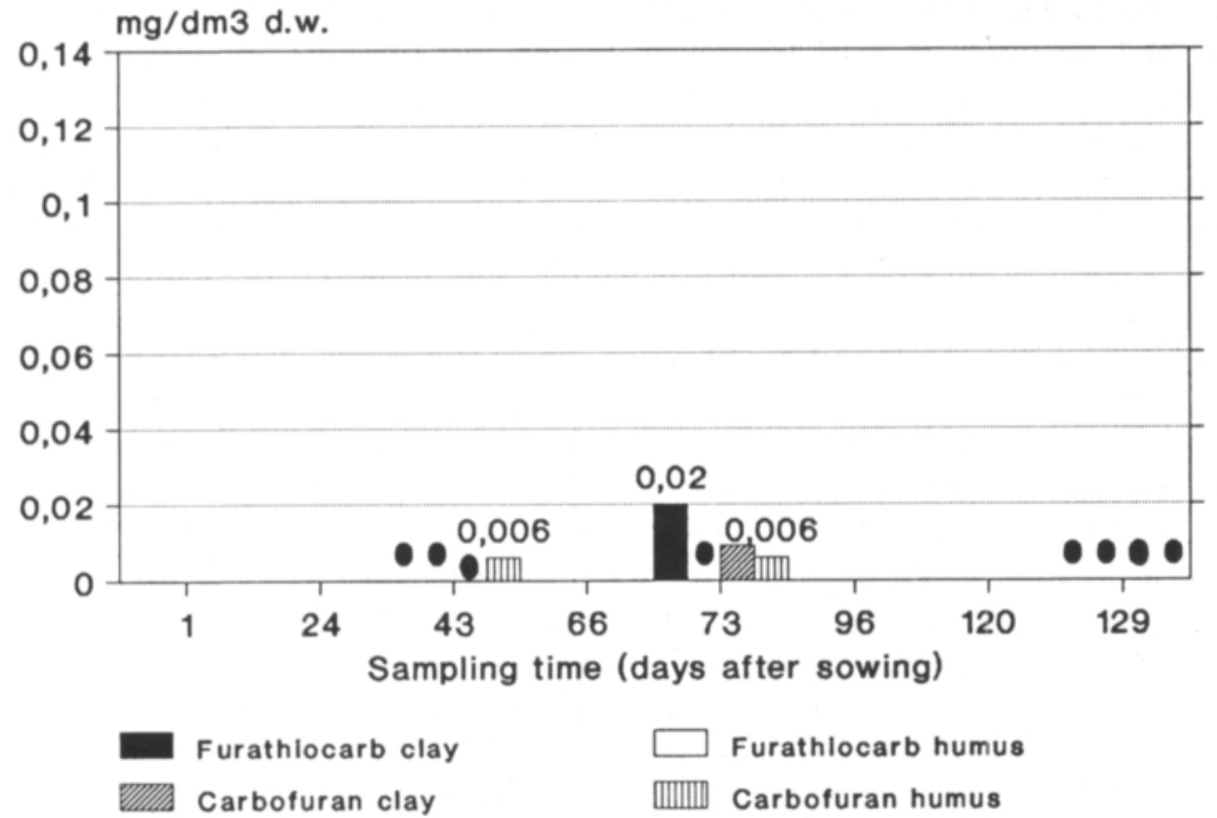

Fig. 7. The concentration of furathiocarb and its degradation product carbofuran $\left(\mathrm{mg} / \mathrm{dm}^{3} \mathrm{dw}\right)$ in the $0-5 \mathrm{~cm}$ layer (Fig. 7.1$)$ and in the $5-15 \mathrm{~cm}$ layer (Fig. 7.2) of the clay and humus soils during the growing season 1988. The compounds were not detected in the finesand soil. A point $(\cdot)$ indicates a value below the determination limit. 
than furathiocarb leaches. This was also observed in this study. Furathiocarb is hardly mobile at all. Only in the clay soil one and half months after the sowing furathiocarb residues were rather surprisingly found in the $5-15 \mathrm{~cm}$ layer. Carbofuran leached in this study as much or less than in the studies mentioned above. Because the acidity of the clay soil of this study may have diminished the mobility of carbofuran, the effect of organic material on the mobility is not very clear.

PUSSEMIER (1989) found in a laboratory study that $50 \%$ of applied furathiocarb degraded to carbofuran in about 16 weeks in a clay soil, which is much the same as the half-lives observed in this study. According to several studies (Pesticide Manual 1987, p. 130), the half-life of carbofuran is 30 - 60 days which is similar to those found in this study. The acidity of a soil and the addition of organic material to a soil reduce the degradation of carbofuran (SomASUNDARAm et al. 1987). This may explain the slower disappearance of carbofuran from the humus soil. But as the disappearance was quicker in the clay soil than in the humus soil, in this study the soil acidity may not have affected the disappearance as much as the contents of organic material. According to HENDRY and RichaRdSON (1988) the degradation of furathiocarb is enhanced if the soil has been treated with the compound earlier. This is also true for carbofuran (e.g.
CHAPMAN et al. 1986, READ 1986 and CAMPER et al. 1987). As the plots of this study had not been previously treated with furathiocarb or carbofuran, their degradation was not enhanced for this reason.

Of the studied pesticides residues of methabenzthiazuron, trifluralin, iprodione, and fenvalerate might have been present in the soils the following spring after the treatment. Their halflives have been calculated to be at most between 80 and 100 days. Thus it can be assumed that if the half-life of a pesticide is equal to or more than this, there may be residues of the substance in Finnish cultivated soils the spring following the treatment.

Acknowledgements. This work was done under a contract from the Finnish Ministry of the Environment and the $\mathrm{Na}$ tional Board of Waters and the Environment. The author made a literature survey of the pesticides and the conclusions of the laboratory results. The results are part of the pesticide field movement and disappearance studies made yearly since 1985 on the initiative of the Finnish Ministry of the Environment at the Institute of Plant Protection of the Agricultural Research Centre and analyzed at the State Institute of Agricultural Chemistry. I would like to extent warm thanks to Leila-Riitta Erviö, Jorma Kurtto, Jukka Salonen, Tuomo Tuovinen, Heikki Hokkanen, Bengt Lindqvist and Helena Granlund for their help. I am especially grateful to Sanni Junnila and Ritva Mutanen for their help and advice. I am also indebted to Kaija Kallio-Mannila, Riitta Silvo and Helvi Heinonen-Tanski for their valuable comments on the manuscript. I also wish to thank Donald Smart for correcting the English.

\section{References}

Allen, R. \& WALKer, A. 1984. Influence of soil microbial activity on herbicide degradation. National Vegetable Research Station. 34th Annual Report 1983. p. 135-136. Wellesbourne, UK.

Aly, M.I., Kraish, A.S. \& BAKRY, N.M. 1986. The influence of soil moisture, light and temperature on the persistence of mephosfolan, fenitrothion and carbaryl in clay loam soil. Alexandria J. Agric. Res. 31, 3: 277-289.

ARnOLD, D.J. \& Briggs, G.G. 1990. Fate of pesticides in soil: predictive and practical aspects. Environmental fate of pesticides. Progr. pesticide biochem. toxicol. 7: 101122. Chichester, England.

BaARsChers, W.H., Elvish, J. \& RYAN, S.P. 1983. Adsorption of fenitrothion and 3-methyl-4-nitrophenol on soils and sediment. Bull. Environ. Contam. Toxicol. 30: 621627.
Bahadir, M., Lorenz, W. \& Korte, F. 1987. Einfluss unterschiedlicher Formulierungen auf die Stabilität und insektizide Wirkungen von Pyrethroiden im Boden. Chemosphere 16: 1311-1317.

Brumhard, B., FÜhr, F. \& Mittelstaedt, W. 1988. Leaching behavior of aged pesticides: standardized soil column experiments with ${ }^{14} \mathrm{C}$-metamitron and ${ }^{14} \mathrm{C}$-methabenzthiazuron. 1987 Brit. Crop Protect. Conf. Weeds. 7A-4: 585-592.

CAmper, N.D., Fleming, M.M. \& SkIPPER, H.D. 1987. Biodegradation of carbofuran in pretreated and non-pretreated soils. Bull. Environ. Contam. Toxicol. 39: 571578.

Chapman, R.A., Tu, C.M., Harris, C.R. \& Cole, C. 1981. Persistence of five pyrethroid insecticides in sterile and natural, mineral and organic soil. Bull. Environm. 
Contam. Toxicol. 26: 513-519.

—, HARRIS, C.R. \& HARRIS, C. 1986. Observations on the effect of soil type, treatment intensity, insecticide formulation, temperature and moisture on the adaption and subsequent activity of biological agents associated with carbofuran degradation in soil. J. Environ. Sci. Health B 21: 125-141.

Determination by gas chromatography. LAB $114252 \mathrm{H}$, BAS 479 H. 1978. Rape (green plants, straw, seed), soybeans (green plants, straw, beans), soil, water. Residue Analysis. Methode Nr. 141. BASF Aktienges. Agric. Res. Station Limburgerhof. GPE/R.

Determination of iprodione (RP-26019) and its major metabolites (RP-30228 \& RP-32490) in soil and water by capillary gas chromatography using a nitrogen/phosphorus detector. Rhone-Poulenc method No. 180. ASD No. 85/157. 1985. REF No. 85/BHL/559/AG. Rhone Poulenc Inc. Agrochem. Div. Monmouth Junction, NJ.

DusejA, D.R. \& Holmes, E.E. 1978. Field persistence and movement of trifluralin in two soil types. Soil Sci. 125: 41-48.

Elmer, W.H. \& StIPES, R.J. 1981. The soil degradation of dicloran, iprodione, and vinclozolin in Lodi loam and Woodstown loamy soils. Phytopath. 71: 872.

— \& STIPES, R.J. 1985. Movement and disappearance of dicloran, iprodione, and vinclozolin in peanut and nonpeanut soils. Pl. Dis. 69: 292-294.

Felsot, A. \& WILSON, J. 1980. Adsorption of carbofuran and movement on soil thin layers. Bull. Environm. Contam. Toxicol. 24: 778-782.

FOHR, F. \& MitTELSTAEDT, W. 1979. Effect of varying soil temperature on the degradation of methabenzthiazuron, isocarbamid and metamitron. Z. Pfl.ernähr. Bodenkd. 142: $657-668$

Gas chromatographic determination besides carbofuran in soil. CGA 73 102. REM 10/82. App. 5. 1983. Ciba-Geigy Ltd. Agric. Div. AG 2.53 Ab/th.

Grover, R., Smith, A.E., Shewchuk, S.R., Cessna, A.J. \& HUNTER, J.H. 1988. Fate of trifluralin and triallate applied as a mixture to a wheat field. J. Environ. Qual. 17: 543-550.

Hayden, B.J. \& Smith, A.E. 1980. Comparison of the persistence of ethalfluralin and trifluralin in Saskatchewan field soils. Bull. Environm. Contam. Toxicol. 25: 508511.

Head, I.M., Cain, R.B., Suett, D.L. \& Walker, A. 1988. Degradation of carbofuran, iprodione and vinclozolin by soil bacteria and initial evidence for plasmid involvement in their metabolism. 1988 Brighton Crop Protect. Conf. Pests and Diseases. 7C-8: 699-704.

HEINONEN-TANSKI, H. 1989. The effect of temperature and liming on the degradation of glyphosate in two arctic forest soils. Soil Biol. Biochem. 21: 313-317.

HeluING, C.S. 1971. Pesticide mobility in soils II. Applications of soil thin-layer chromatography. Soil Sci. Soc. Amer. Proc. 35: 737-743.
HeNDRY, K.M. \& Richardson, C.J. 1988. Soil biodegradation of carbofuran and furathiocarb following soil pretreatment with these pesticides. Environ. Toxicol. Chem. 7: 763-774.

HILL, B.D. 1981. Persistence and distribution of fenvalerate residues in soil under field and laboratory conditions. J. Agric. Food. Chem. 29: 107-110.

JaCQUeS, G.L. \& HARVEY, R.G. 1979. Persistence of dinitroaniline herbicides in soil. Weed Sci. 27: 660-665.

JARCZYK, H.J. 1972. Gaschromatographische Methode zur Bestimmung von Tribunil-Rückständen in Boden, Wasser und Pflanzenmaterial. Pfl.schutz-Nachr (Bayer) 25: 21-31.

Jensen, K.I.N. \& Kimball, E.R. 1980, Persistence of trifluralin in Nova Scotia, Canada. Bull. Environm. ' Contam. Toxicol. 24: 238-243.

KREUGER, J. 1986. Läckage av MCPA och diklorprop från åker. Innehåll av bekämpningsmedel $\mathrm{i}$ åar. Nord. Jordbr.forskn. 68: 379-380.

— \& BRINK, N. 1988. Losses of pesticides from arable land. Văxtskyddsrapp. Jordbr. 49: 50-61.

Kubiak, R., Führ, F., Mittelstaedt, W., Hansper, M. \& SteFfens, W. 1988. Transferability of lysimeter results to actual field situations. Weed Sci. 36: 514-518.

Kurki, M., Lakanen, E., Mä́inen, O., SillanpäĀ, M. \& VUORINEN, J. 1965. Viljavuusanalyysien tulosten ilmoitustapa ja tulkinta. Summary: Interpretation of soil testing results. Ann. Agric. Fenn. 4: 145-153.

Lafleur, K.S., MCCASKILL, W.R. \& Gale, G.T., JR. 1978. Trifluralin persistence in Congaree soil. Soil Sci. 126: 285-289.

LeE, H.-B. \& ChaU A.S.Y. 1983. Gas chromatographic determination of trifluralin, diallate, triallate, atrazine, barban, diclofop-methyl, and benzoylprop-ethyl in sediments at parts per billion levels. J. Assoc. Off. Anal. Chem. 66: 1322-1326.

LEE, P.W. 1985. Fate of fenvalerate (pydrin insecticide) in the soil environment. J. Agric. Food Chem. 33: 993-998.

Lichtenstein, E.P. \& Liang, T.T. 1987. Effects of simulated rain on the transport of fonofos and carbofuran from agricultural soils in a three-part environmental microcosm. J. Agric. Food Chem. 35: 173-178.

MCDowelL, L.L. 1987. Fenvalerate wash-off from cotton plants by rainfall. Pestic. Sci. 21: 83-92.

Månadsöversikt över Finlands klimat. 1985-1988. Maj-september. Meteorologiska Institutet.

MiKaMI, N. 1987. Degradation of pyrethroid insecticides in the environment. J. Pestic. Sci. 12: 539-548.

—, Sakata, S., Yamada, H. \& MiYamoto, J. 1985. Further studies on degradation of fenitrothion in soils. J. Pestic. Sci. 10: 491-500.

Nitsson, H. 1985. Herbicide persistence and mobility in arable soil. Investigations in 1982-1983. 26th Swed. Weed Conf. Rep. 1: 217-224. Sver. Lantbr.univ. Uppsala.

Pestemer, W. 1977. Verhalten gemüsebaulich genutzter 
Harnstoff-Herbizide in sorptionstarken Böden. Z Pfl.krankheiten Pfl.schutz. Sonderh. VIII: 259-270.

- 1988. Ausbreitung und Abbau von Herbiziden im Boden. Mitt. Schw. Landw. 36: 2-17.

— \& Auspurg, B. 1987. Prognose-Modell zur Erfassung des Rückstandsverhaltens von Metribuzin und Methabenzthiazuron im Boden und deren Auswirkungen auf Folgekulturen. Weed Res. 27: 275-286.

Pesticide Manual. 1987. 1081 p. 8th Ed. Thornton Heath. England.

Probst, G.W., Golab, T., Herberg, R.J., Holzer, F.J., Parka, S.J., Schans, C. van der \& TePE, J.B. 1967. Fate of trifluralin in soils and plants. J. Agric. Food Chem. 15: 592-599.

PUSSEMIER, L. 1988. Recherches sur la réduction des doses en traitement insecticide du sol en culture de betteraves. Comportement du furathiocarbe et du carbofuran suivant divers modes d'application. Rev. de l'Agric. 41: 595604.

- 1989. Enrobage des semences et controle de la liberation du carbofuran dans le sol. Meded. Fac. Landbouwwetensch. Rijksuniv. Gent 54: 269-277.

READ, D.C. 1986. Accelerated microbial breakdown of carbofuran in soil from previously treated fields. Agric. Ecosystems Environm. 15: 51-61.

Rouchaud, J., Metsue, M., Van Himme, M., Gillet, J., BeNOIT, F. \& VANPARIJS, L. 1989. Soil metabolism of the herbicide metazachlor in barley and vegetable crops. Meded. Fac. Landbouwwetensch. Rijksuniv. Gent 54: 257-261.

Sharma, S.R., Singh, R.P. \& Ahmed, S.R. 1985. Effect of different saline, alkaline salts, fertilizers, and surfactants on the movement of some phosphorus-containing pesticides in soils. Ecotoxicol. Environm. Safety. 10: 339350.

Singh, R.P., Kumari, K. \& SAXENA, S.K. 1987. Adsorption thermodynamics of carbofuran on acid and base saturated soils. Ecotoxicol. Environm. Safety 13: 253-260.

SOMASUNDARAm, L., RACKE, K.D. \& CoATS, J.R. 1987. Effect of manuring on the persistence and degradation of soil insecticides. Bull. Environ. Contam. Toxicol. 39: $579-586$
Takimoto, Y., Hirota, M., InUI, H. \& Miyamoto, J. 1976. Decomposition and leaching of radioactive Sumithion in 4 different soils under laboratory conditions. J. Pestic. Sci. 1: 131-143.

— \& Мгяамото, J. 1976. Residue analysis of Sumithion. Residue Rev. 60: 83-101. New York.

TALEKAR, N.S., KAO, H.T. \& CHEN, J.S. 1983. Persistence of selected insecticides in subtropical soil after repeated biweekly applications over two years. J. Econ. Entomol. 76: 711-716.

TePE, J.B. \& SCroggs, R.E. 1967. Trifluralin. Analytical methods for pesticides, plant growth regulators, and food additives. 5: Additional principles and methods of analysis. p. 527-535. New York.

WALKER, A. 1987 a. Evaluation of a simulation model for prediction of herbicide movement and persistence in soil. Weed Res. 27: 143-152.

- 1987 b. Further observations on the enhanced degradation of iprodione and vinclozolin in soil. Pestic. Sci. 21: 219-231.

— \& BROWN, P.A. 1985. The relative persistence in soil of five acetanilide herbicides. Bull. Environ. Contam. Toxicol. 34: 143-149.

—, Brown, P.A. \& ENTwistle, A.R. 1986. Enhanced degradation of iprodione and vinclozolin in soil. Pestic. Sci. 17: 183-193.

—, Entwistle, A.R. \& Dearnaley, N.J. 1984. Evidence for enhanced degradation of iprodione in soils treated previously with this fungicide. BCPC Monogr. No. 27. Symp. on soils and crop protect. chem. p. 117-123.

Williams, I.H. \& Brown, M.J. 1979. Persistence of permethrin and WL 43775 in soil. J. Agric. Food Chem. 27: 130-132.

\section{Manuscript received December 1991}

Hannu Braunschweiler

University of Helsinki

Department of Environmental Concervation

Viikki

SF-00710 Helsinki, Finland 


\title{
SELOSTUS
}

\section{Eräiden torjunta-aineiden käyttäytyminen suomalaisissa viljelymaissa}

\author{
HaNNU BRAUNSCHWEILER \\ Helsingin yliopisto
}

\begin{abstract}
Ympäristöministeriön aloitteesta on vuodesta 1985 lähtien tutkittu vuosittain muutaman torjunta-aineen häviämistă ja kulkeutumista viljelymaiden maaperässä. Tavoitteena on ollut selvittäă torjunta-aineiden käyttäytymistä maaperässä Suomen olosuhteissa ja verrata tuloksia ulkomaisiin laboratorio- ja kenttăkokeisiin.

Vuosina 1985 - 1988 tutkittiin metabentstiatsuronin, metatsaklorin, trifluraliinin, iprodionin, fenitrotionin, fenvaleraatin ja furatiokarbin pysyvyyttă ja kulkeutumista. Kenttäkokeet tehtiin Maatalouden tutkimuskeskuksessa kasvinsuojelun tutkimuslaitoksessa Jokioisissa. Torjunta-aineet ja niiden hajoamistuotteet määritettiin kemiallisesti Valtion maatalouskemian laitoksella. Aineiden käyttäytymistä tutkittiin kolmessa eri maalajissa: savimaassa, hietamaassa ja runsaasti orgaanista ainesta sisăltăvăssă maassa (multa- tai turvemaa). Maanäytteită otettiin kolmesta eri syvyydestä yhdisteiden kulkeutumisen seuraamiseksi. Yhdisteiden häviämistä seurattiin yleensă yhden kasvukauden ajan.

Tarkastelluista torjunta-aineista metabentstiatsuroni kulkeutui eniten ja metatsaklori lăhes yhtă paljon. Molemmat
\end{abstract}

yhdisteet kulkeutuivat kuukaudessa yli $15 \mathrm{~cm}: n$ syvyyteen. Fenitrotioni ja fenvaleraatti kulkeutuivat văhiten. Trifluraliini oli torjunta-aineista kaikkein pysyvin ja fenitrotioni nopeimmin hajoava. Iprodionin ja fenvaleraatin pitoisuudet maaperässă kasvoivat syksyă kohti. Tämä johtui ilmeisesti siitä, ettă osa näistä torjunta-aineista jäi käsittelyssă kasvustoon, josta ne vähitellen huuhtoutuivat maahan.

Mineraalimaista kasvukauden lopussa pintamaasta mitatut trifluraliinipitoisuudet voivat olla haitallisia trifluraliinille herkille viljelykasveille. Turvemaan pintakerroksesta havaittiin vielă 1.5 vuoden kuluttua kăsittelystă korkeahkoja trifluraliinijäämiä. Muista tarkastelluista torjunta-aineista metabentstiatsuronia, iprodionia ja fenvaleraattia olisi todennäköisesti ollut vielä määritettäviä pitoisuuksia seuraavana keväănă. Trifluraliinin, metabentstiatsuronin, iprodionin ja fenvaleraatin puoliintumisajoiksi on saatu enimmillään noin $80-100$ vuorokautta. Torjunta-ainetta voitaneen havaita seuraavana keväänä suomalaisissa viljelymaissa, jos yhdisteen puoliintumisaika on văhintäăn kyseisten arvojen suuruinen. 